\title{
Sýking í gervilið í hné eftir endurteknar liðástungur
}

\author{
Eypór Örn Jónsson ${ }^{1}$, Hera Jóhannesdóttir², Anna Stefánsdóttir ${ }^{3}$ \\ Höfundar eru öll læknar.
}

\section{ÁGRIP}

Áttræður karlmaður fékk sýkingu í gervilið í hné eftir endurteknar liðástungur. Stungið var á liðnum vegna liðblæðinga í kjölfar áverka á sin fjórhöfðavöðva læris ( $m$. quadriceps femoris) en sá áverki greindist pó ekki í upphafi. Til að̃ uppræta sýkinguna reyndist nauðsynlegt að framkvæma staurliðsaðgerð. Tilfellið undirstrikar að gerviliðir eru næmir fyrir sýkingum. Ígrunda barf vandlega ákvörðun um að stinga á gervilið. Nauðsynlegt er að hafa áverka á sin fjórhöfðavöðva læris í huga við áverka sem valda liðblæðingu. Rætt er um sýkingar í gerviliðum með áherslu á greiningu og fyrstu skref meðferðar.

Fyrirspurnir: Eypór Örn Jónsson, eythororn@gmail.com

${ }^{1}$ Bæklunarskurðdeild Sahlgrenska háskólasjúkrahússins í Gautaborg, Svípjóð ${ }^{2}$ bæklunarskurðdeild Landspítala, 3bæklunarskurðdeild háskólasjúkrahússins á Skáni, Svípjód

\section{Inngangur}

Sýkingar eru einn alvarlegasti fylgikvilli liðskiptaaðgerða og meðferðin krefst langrar legu á sjúkrahúsi, er mjög kostnaðarsöm og hefur neikvæð áhrif á lífsgæði. Tíðni sýkinga í gerviliðum í hnjám var 1,4\% í nýlegri finnskri rannsókn. ${ }^{2}$ Staphylococcus aurues og kóagúlasa neikvæðir stafýlókokkar eru algengustu sýkingarvaldarnir. ${ }^{3}$ Flestar sýkingar koma upp á fyrstu premur mánuðunum eftir ísetningu á gervilið í hné en tíðnin minnkar verulega með tímanum. ${ }^{4}$ Erfitt er að sýna fram á hvernig bakteríur sem valda sýkingum í gerviliðum komast inn í liðinn. Sú hugmynd er pó útbreidd að pað gerist oftast við aðgerðina pegar gerviliðnum er komið fyrir pó einkennin komi ekki alltaf fram fyrr en að einhverjum tíma liðnum. ${ }^{5}$ Sýkingar í gerviliðum geta einnig verið blóðbornar en pær geta komið fram á hvaða tíma sem er eftir aðgerð. Skilgreiningin á blóðborinni sýkingu er breytileg á milli rannsókna, sem og tíðnin sem pær gefa upp. Í rannsókn sem náði til 478 tilfella í Svípjóð töldust 20\% vera blóðbornar sýkingar. ${ }^{4}$ Sýkingarvaldur getur einnig komist inn í liðinn með beinum hætti en flestar rannsóknir gera ekki sérstaklega grein fyrir pessum hópi. Í fyrrgreindri rannsókn frá Svípjóð voru 5,7\% tilvika talin vera afleiðing sýkinga í nærliggjandi vefjum meðal annars eftir skurðaðgerðir á beinum og mjúkvefjum en í einu tilviki $(0,2 \%)$ eftir liðástungu og innspýtingu barkstera.

\section{Tilfelli}

Áttræður karlmaður með slitgigt og gervilið í báð- sem bætt var við plasthluta á hnéskelina. Verkirnir sem hann hafði verið með löguðust eftir enduraðgerðina.

Skoðun á bráðamóttöku leiddi í ljós liðblæðingu (hemarthrosis) en engin beinbrot greindust á röntgenmynd. Engin greining var ákvörðuð né sértæk meðferð veitt. Í kjölfarið leitaði hann endurtekið á heilsugæslustöð vegna vökvasöfnunar í hnénu. Á 7 vikna tímabili var stungið 20 sinnum á liðnum og blóðugur liðvökvi tæmdur út.

Sex vikum eftir síðustu ástunguna leitaði hann á bráđamóttöku á ný vegna verks í vinstra hné sem byrjaði skyndilega sólarhring áður. Hann var hitalaus $\left(37,6^{\circ} \mathrm{C}\right)$. Talsverður vökvi var í liðnum auk pess sem húðin umhverfis var rauð og heit. CRP mældist 142 mg/L. Framkvæmd var liðástunga og í liðvökvanum voru 26.000 hvít blóðkorn/ $\mu \mathrm{L}$, par af voru daufkyrningar 93\%. Liðvökvinn var sendur í bakteríuræktun. Sjúklingurinn lagðist inn á smitsjúkdómadeild og fékk vankómýcín í æð. Liðurinn var hreinsaður á skurðstofu premur dögum eftir innlögn. Ræktanir sem teknar voru í aðgerðinni voru neikvæðar en kóagúlasa-neikvæðir stafýlókokkar ræktuðust úr liðvökvanum frá ástungunni og voru peir næmir fyrir kloxacillíni sem sjúklingurinn var pá meðhöndlaður með í æð í tvær vikur. Að pví búnu útskrifaðist hann á ofloxacín-töflum og rífampicín-hylkjum.

Rúmum mánuði síðar kom hann til eftirlits. Hann hafði haft verki í hnénu og pað var enn nokkuð bólgið. Við skoðun kom fram að sin fjórhöfðavöðva læris var slitin. Vegna pess hversu langt var liðið frá áverkanum hafði vöðvinn dregist saman og bilið á milli enda sinarinnar var pví orðið stórt. Við slíkar aðstæður er talsvert erfitt að gera við sinina. Án réttigetu hefði nýr gerviliður sem hluti af skurðmeðferð vegna sýkingarinnar hins vegar ekki nýst sjúklingnum nema að takmörkuðu leyti. Til greina kom að framkvæma 


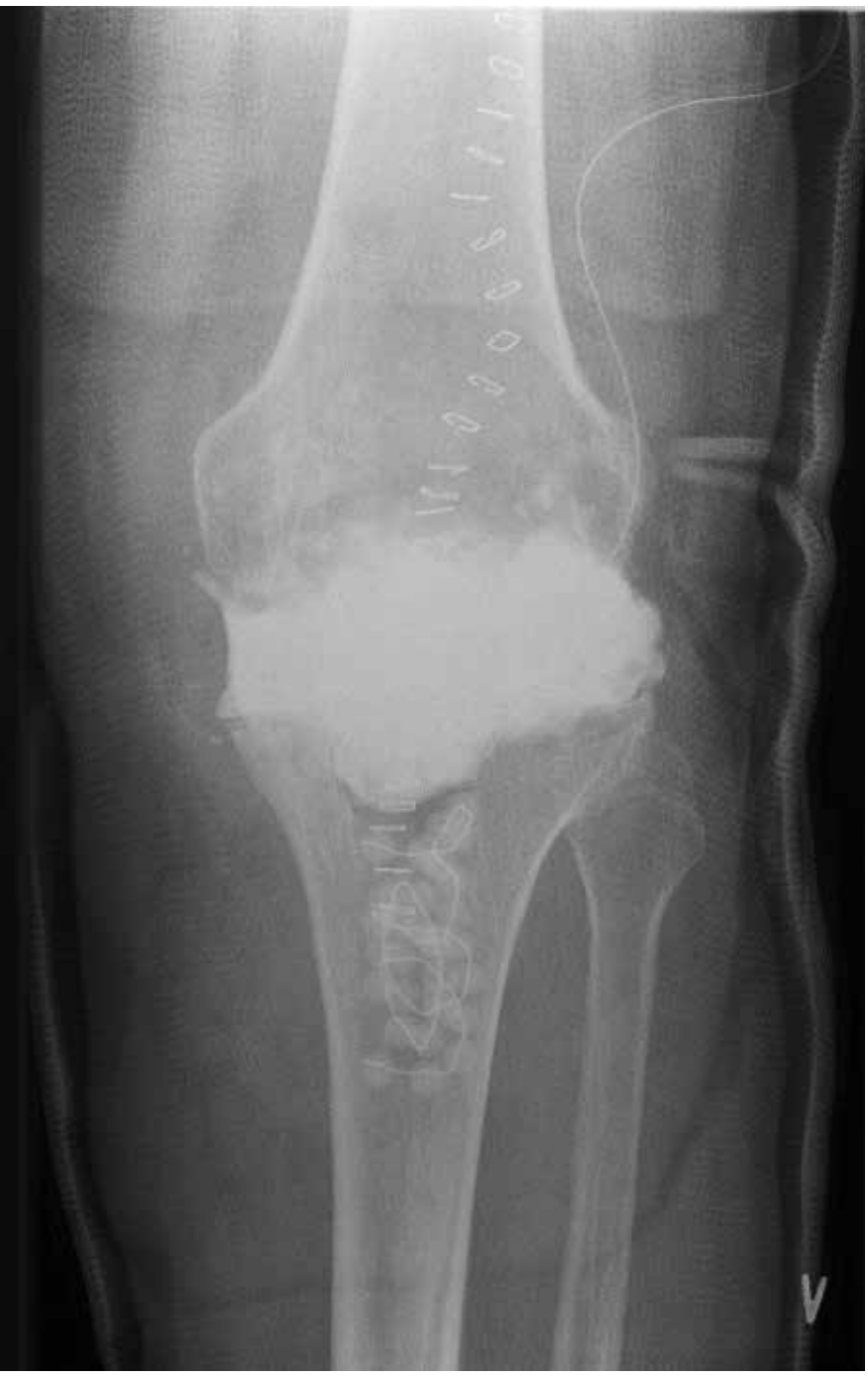

Mynd 1. Röntgenmynd af vinstra hné sjúklingsins. Gerviliðurinn hefur verið fjarlægður og fyllingu sem gerð er úr beinsementi komið fyrir í liðnum.

staurliðsaðgerð en ákveðið var að bíða með pað að sinni og halda sýklalyfjameðferð áfram.

Fimm mánuðum frá fyrstu innlögninni leitaði sjúklingurinn enn á ný á bráðamóttöku, með tveggja daga sögu um verki og bólgu í hnénu. CRP var 180 og sökk 66. Í liðvökva voru 60.700 hvít blóðkorn/ $\mu \mathrm{L}$. Ákveðið var að hætta meðferð með ofloxacíni og rífampicíni en láta reyna á bælimeðferð með klindamýsín töflum í staðinn. Sú meðferð gagnaðist í eitt ár en pá fór ástandið versnandi með auknum verkjum og vökvasöfnun í liðnum ásamt hækkandi sökki og CRP. Staphylococcus aureus ræktaðist úr liðvökva og var pað túlkað sem ný sýking ofan á hina fyrri (secondary infection).

Staurliðsaðgerð var pá framkvæmd í tveimur prepum en í fyrri aðgerðinni var gerviliðurinn fjarlægður, liðurinn hreinsaður og komið fyrir fyllingu gerðri úr beinsementi sem innihélt gentamícín (mynd 1). Sjúklingurinn var meðhöndlaður með kloxacillíni í æð. Pegar klínísk einkenni sýkingar voru horfin og sökk og CRP hafði lækkað premur mánuðum síðar var liðurinn stífður með mergnagla (mynd 2).

Við eftirlit eftir fjóra mánuði voru engin sýkingarmerki til staðar.

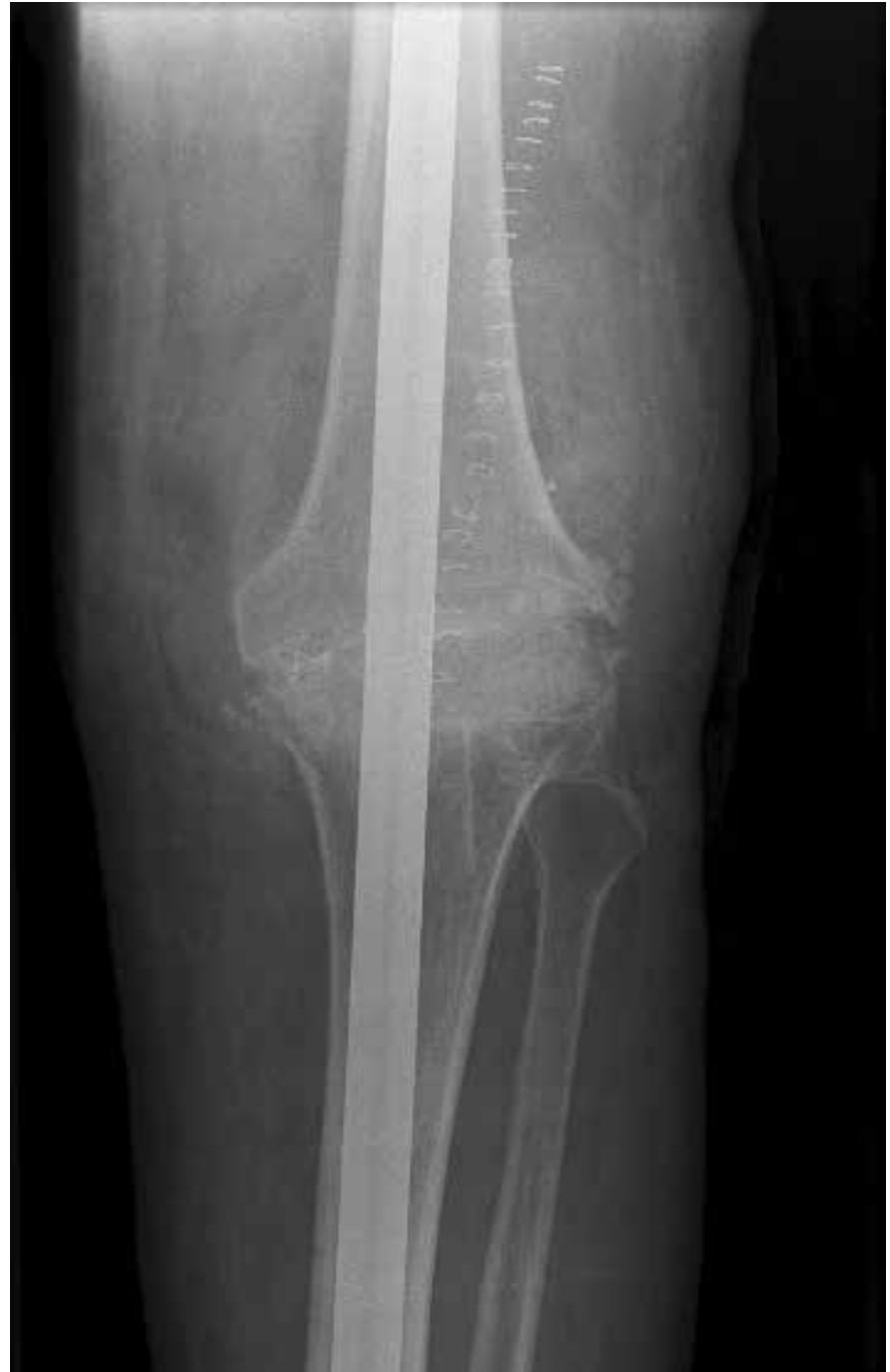

Mynd 2. Röntgenmynd sem sýnir vinstra hné sjúklingsins eftir að framkvæmd hefur verið staurliðsaðgerð með mergnagla.

\section{Umræða}

Sjúklingurinn var með sýkingu í gervilið í hné. Sýkingar af völdum kóagúlasa-neikvæðra stafýlókokka geta verið einkennalitlar. Líklegast pykir að bakterían hafi komist inn í liðinn við einhverja ástunguna pó ekki sé hægt að útiloka blóðborna sýkingu. Рað er ómögulegt að vita með vissu hvernig bakteríurnar komust inn í liðinn en við teljum engu að síður að tilfellið gefi tilefni til að vekja athygli á pví að gerviliðir eru næmir fyrir sýkingum og ástungum á gerviliði fylgir sýkingarhætta. Við viljum jafnframt vekja athygli á pví hvernig greiningu og meðferð er best háttað en hún víkur í vissum atriðum frá pví pegar um eigin lið (native joint) er að ræða, pað er að segja lið án gerviliðar.

Liðblæðing (hemarthrosis) fylgir gjarnan áverkum á mjúkvefi eða bein aðlægt hnéliðnum eins og í pessu tilfelli. Brot greinast oftast á röntgenmynd en mjúkvefjaáverka getur verið erfitt að greina í upphafi meðal annars vegna pess að verkir hindra fullnægjandi skoðun. Við liðblæðingu eftir áverka á hnjám án gerviliða er til staðar áverki á fremra krossbandið í 58\% tilvika og á liðpófum í 33\%. ${ }^{6}$ Pannig eru verulegar líkur á pví að pað sé til staðar áverki með klíníska pýðingu ef pað blæðir í hnéliðinn eftir áverka. 
Tafla I. Skilgreining MSIS (Muskuloskeletal Infection Society) á sýkingu í gervilið. Sýking er til staðar ef eitt af tveimur meiriháttar skilmerkjum er uppfyllt eða fjögur af sex minniháttar skilmerkjum. ${ }^{14}$

Meiriháttar skilmerki (Major criteria)

Fistill með samgang við gerviliðinn er til staðar

Sýkill ræktast frá tveimur aðskildum vefja- eđa liðvökvasýnum sem tekin eru frá liðnum

Minniháttar skilmerki (Minor criteria)

Hækkað sökk og CRP

Hækkuð hvít blóðkorn í liðvökva

Hækkað hlutfall daufkyrninga í liðvökva

Gröftur er til staðar í liðnum

Sýkill ræktast frá einu vefja- eða liðvökvasýni sem tekið er frá liðnum

Hækkað hlutfall daufkyrninga í vefjasýni frá liðnum*

*Fleiri en 5 daufkyrningar á felt i 5 feltum pegar skoðað er með 400-faldri stækkun

Pví er skynsamlegt að fylgja pessum sjúklingum eftir pegar liðnir eru 10-14 dagar frá áverka. Pá hefur bólga og verkur oft minnkað og líklegra er að skoðun gagnist við að ákvarða greiningu. Ekki liggja fyrir tíðnitölur um orsakir liðblæðinga eftir áverka pegar gerviliður er til staðar. Ljóst er að áverkar á fremra krossband og liðpófa koma ekki til greina par sem hvort tveggja er fjarlægt við liðskiptaaðgerðir og pví er nauðsynlegt að leita annarra skýringa.

Rof á fjórhöfðavöðva læris er mismunagreining við liðblæðingu í hné eftir áverka á bæði eigin lið og pegar gerviliður er til staðar. Greiningin getur verið vandasöm eins og raunin var í pessu tilfelli en áverkinn greinist ekki við fyrstu skoðun í allt að $38 \%$ tilvika. ${ }^{7}$ Í einhverjum tilvikum má rekja petta til pess að kröftug liðblæðing dylur pá gróp sem myndast rétt ofan við hnéskelina par sem algengast er að sinin rofni. Oftast er til staðar máttleysi í réttu (extension) á hnénu. Greiningin verður enn erfiðari ef aðeins er um að ræða hlutaáverka (partial rupture) par sem fyrrnefnd gróp verður ekki jafn áberandi og réttikraftur hverfur ekki að fullu. Í hnjám með gervilið er algengi rofs á fjórhöfðavöðva læris á bilinu 0,1 til $1,1 \%{ }^{8}$

Ef vafi leikur á greiningunni eftir klíníska skoðun er oft gerð ómskoðun en niðurstaðan getur verið breytileg eftir pví hvaða röntgenlæknir framkvæmir rannsóknina. Perfitt og félagar lýstu pví að næmi ómskoðunar væri $100 \%$ en sértækið aðeins $67 \%{ }^{9}$ Til að forðast óparfa meðferð parf að hafa petta í huga áður en ómskoðun er pöntuð og við túlkun á niðurstöðunum ef hún er framkvæmd. Ein lausn gæti verið að framkvæma segulómskoðun en næmi og sértæki hennar var 100\% í fyrrgreindri rannsókn. Рað hefur til skamms tíma verið vandkvæðum bundið að framkvæma segulómskoðun pegar gerviliður er til staðar en með bættri tækni hafa möguleikarnir á pví að greina mjúkvefjaáverka nálægt gerviliðum aukist.

Pegar liðblæðing er til staðar eftir áverka á hné er stundum stungið á liðnum til að tæma út blóðið. Út frá peim rannsóknum sem gerðar hafa verið er hvorki hægt að mæla með eða á móti liðástungu við pessar aðstæður. ${ }^{6}$ Mögulegur ávinningur felst í minni verkjum og aukinni hreyfigetu en hann parf að vega upp á móti sýkingarhættu, auk pess sem tilhneigingin er sú að pað safnist aftur fyrir blóð í liðnum skömmu eftir ástungu. Árni Jón Geirsson og félagar áætluðu að sýkingartíðnin eftir liðástungur á Íslandi væri 0,037\%.10 Áætlað hefur verið að í nágrenni við aðskotahlut purfi 100.000 sinnum minna magn af Staphylococcus aureus til að valda sýkingu en pegar aðskotahlutur er ekki til staðar. ${ }^{5}$ Gerviliður hefur verið talinn frábending fyrir liðástungu. Hvað varðar liðblæðingu eftir áverka á eigin lið framkvæma höfundar sjaldan liðástungu, helsta ábendingin væri sú að sjúklingurinn hafi mikla verki í hvíld.

Til að greina sýkingar í gerviliðum er nauðsynlegt að vera vel á varðbergi pví birtingarmyndin getur verið lúmsk. Félögin American Academy of Orthopaedic Surgeons og Infectious Diseases Society of America hafa hvort um sig gefið út leiðbeiningar um uppvinnslu á sýkingum í gerviliðum.11,12 Í peim kemur fram að grunur um sýkingu í gervilið ætti að vakna við bæði bráða og langvarandi verki sem og við viðvarandi vessa frá skurðsári eða tilvist fistils. Hækkun á hvítum blóðkornum eða hiti eru ekki forsenda fyrir greiningu enda einungis til staðar hjá hluta sjúklinga. Mælst er til pess að CRP og sökk sé mælt ef grunur er um sýkingu í gervilið. Ef bæði próf eru hækkuð er næmið 96-100\% og sértækið 79-93\%. ${ }^{3}$ Taka skal röntgenmynd. Ef sjúklingurinn er með hita, ef einkenni komu hratt fram eða grunur er um bakteríudreyri (bacteremia) skal senda blóð í ræktun. Liðástunga er mikilvægur hluti uppvinnslunnar. Pegar um eigin liði er að ræða er sú hugmynd útbreidd að miða greininguna á liðsýkingu við fleiri en 50.000 hvít blóðkorn/ $\mu \mathrm{l}$ í liðvökva, pótt réttmæti pessara marka hafi verið dregið í efa. ${ }^{13}$ Mörkin eru mun lægri pegar um gervilið er að ræða. Við bráðar sýkingar í gerviliðum í hnjám hefur verið lagt til að miða við 20.000 hvít blóðkorn/ $\mu 1$ en 1100-4000 í langvinnum sýkingum. ${ }^{14}$ Nauðsynlegt er að senda liðvökva í bakteríuræktun. Til að auka líkur á pví að sýkingarvaldur ræktist er talinn kostur að bíða með gjöf sýklalyfja ef ástand sjúklingsins leyfir pangað til allar fyrirhugaðar sýklaræktanir hafa verið teknar, bæði með ástungu en einnig vefjasýni ef opin aðgerð er fyrirhuguð.

Skilgreiningin á sýkingu í gervilið hefur til skamms tíma verið á reiki sem hefur torveldað samanburð á vísindarannsóknum. Árið 2011 setti hins vegar MSIS (Muskuloskeletal Infection Society) fram skilgreiningu á sýkingu í gervilið (tafla I). ${ }^{14}$ Sýking telst vera til staðar ef eitt meiriháttar skilmerki (major criteria) er uppfyllt eða fjögur minniháttar skilmerki (minor criteria). Deilt er um notagildi smásjárskoðunar á vefjasýnum og ef hún er ekki framkvæmd nægja prjú undirskilmerki til að sýking teljist vera til staðar. ${ }^{3}$ Mikilvægt er að meta hvert tilfelli fyrir sig en sýking getur verið til staðar pó að pessi skilmerki séu ekki uppfyllt, sérstaklega ef um er að ræða sýkla með lága meinvirkni (virulence) svo sem Propionibacterium acnes.

Bakteríur sem valda sýkingum í gerviliðum hafa tilhneigingu til að safnast saman í örverupekju (biofilm). Frumur ónæmiskerfisins og sýklalyf eiga erfitt með að vinna á bakteríum í örverupekju, hugsanlega vegna pess аð pað hægist verulega á efnaskiptum bakteríanna. ${ }^{5}$ Hreinsun með skurðaðgerð getur komið að gagni við meðhöndlun á sýkingum í gerviliðum. Рað tekur tíma fyrir örverupekju að myndast og pví hefur pað vissa pýðingu við val á tegund skurðmeðferðar hversu lengi einkenni sýkingar hafa verið til staðar. ${ }^{12}$ Ef einkenni hafa staðið í minna en prjár vikur eða koma upp innan við 30 dögum frá frumaðgerð pá mæla fyrrgreindar leiðbeiningar Infectious Diseases Society of America með skurð- 
aðgerð par sem sýktir mjúkvefir eru fjarlægðir, liðurinn skolaður og skipt um pá hluta gerviliðarins sem ekki eru fastir við bein (til dæmis plasthluta sköflungs ef um gervilið í hné er að ræða). Раð er forsenda fyrir pessari meðferð að sjálfur gerviliðurinn sitji vel fastur við bein. Fistill er frábending. Mælt er með gjöf sýklalyfs í æð samkvæmt næmi í 2-6 vikur eftir slíka aðgerð. Par á eftir fylgir meðferð í töfluformi með rífampicín ásamt öðru lyfi en par eru lyf af flokki flúorókínaólóna fyrsta val. Meðferðinni er haldið áfram í 6 mánuði í peim tilgangi að uppræta sýkinguna. Í pví tilfelli sem hér er lýst var notað ofloxacín sem er ekki lengur fáanlegt en nota má önnur lyf af flokki flúorókínaólóna, svo sem ciprófloxacín. Ef sýkingin hefur staðið lengur en í prjár vikur er mælt með að allur gerviliðurinn sé fjarlægður og er oft framkvæmd svokölluð tveggja prepa aðgerð. Við fyrri aðgerðina er gerviliðurinn fjarlægður ásamt sýktum mjúkvefjum og dauðu beini og í staðinn sett inn fylling úr beinsementi sem er í laginu eins og gerviliður. Pá tekur við sýklalyfjameðferð í 6 vikur. Til að meta hvort sýking hafi verið upprætt er meðal annars stuðst við mælingar á CRP og sökki. Ef tekist hefur að uppræta sýkingu er seinni aðgerðin framkvæmd en pá er nýjum gervilið komið fyrir. Tveggja prepa aðgerð er mun umfangsmeiri og erfiðari fyrir sjúklinginn auk pess að hafa í för með sér meira álag á heilbrigðiskerfið. Pví er til mikils að vinna með pví að greina sýkingar í gerviliðum tímanlega.

Í pví tilfelli sem lýst er hér takmörkuðust meðferðarmöguleikarnir verulega vegna pess að sjúklingurinn var með sýktan gervilið í hné og rof á sin fjórhöfðavöðva læris. Ein og sér eru bæði pessi vandamál mjög erfið viðureignar. Fjölmörgum mismunandi aðgerðum hefur verið lýst til að gera við rof á sin fjórhöfðavöðva læris pegar gerviliður er til staðar. Engin peirra hefur pó reynst leiða til ásættanlegs árangurs með áreiðanlegum hætti. ${ }^{8}$ Í okkar tilfelli greindist áverkinn eftir töf sem jók enn frekar á vandann. Рað getur einnig reynst erfitt að meðhöndla sýkingar í gerviliðum í hnjám. Tíðni pess að pað mistækist að uppræta slíkar sýkingar lá á bilinu 0-31\% í safngreiningu (meta-analysis) Jämsen og félaga sem tók bæði til rannsókna á skurðmeðferð í einu prepi og tveimur prepum $^{15}$.

Hér hefur verið fjallað um mann sem fékk sýkingu í gervilið í hné sem ekki var unnt að uppræta fyrr en gerð var staurliðsaðgerð. Рað er mikilvægt að hafa í huga að gerviliðir eru næmir fyrir sýkingum og samkvæmt skoðun greinarhöfunda ætti ekki að framkvæma liðástungu á gervilið nema að höfðu samráði við bæklunarskurðlækni. Pað er nauðsynlegt að hafa rof á fjórhöfðavöðva læris í huga pegar áverki hefur orðið á hné pví eins og petta tilfelli sýnir getur greiningin verið erfið og töf á greiningu haft vandamál í för með sér. Tímanleg og rétt greining á sýkingu í nálægð við gervilið í hné er gríðarlega mikilvæg til að minnka líkur á umfangsmiklum aðgerðum og verulega skertum lífsgæðum. Í pví samhengi er vert að hafa í huga að við sýkingu í gervilið geta hvít blóðkorn í liðvökva verið heldur lægri en við sýkingu í eigin lið.

\section{Heimildir}

1. Whitehouse JD, Friedman ND, Kirkland KB, Richardson WJ, Sexton DJ. The impact of surgical-site infections following orthopedic surgery at a community hospital and a university hospital: adverse quality of life, excess length of stay, and extra cost. Infect Control Hosp Epidemiol 2002 23: 183-9.

2. Huotari K, Peltola M, Jamsen E. The incidence of late prosthetic joint infections. Acta Orthop 2015; 86: 1-5.

3. Parvizi J. Periprosthetic joint infection: Practical Management Guide. Jaypee Brothers Medical Publishers, Nýju Delhí 2013.

4. Stefansdottir A. The infected knee arthroplasty [dissertation]. Lund University, Lundi 2010.

5. Zimmerli W, Trampuz A, Ochsner PE. Prosthetic-join infections. N Engl J Med 2004; 351: 1645-54.

6. Bhandari M, Adili A. Evidence-based orthopedics. WileyBlackwell, Oxford 2011
7. Siwek CW, Rao JP. Ruptures of the extensor mechanism of the knee joint. J Bone Joint Surg Am 1981; 63: 932-7.

8. Bates MD, Springer BD. Extensor Mechanism Disruption After Total Knee Arthroplasty. J Am Acad Orthop Surg 2015; 23: 95-106.

9. Perfitt JS, Petrie MJ, Blundell CM, Davies MB, Acute quadriceps tendon rupture: a pragmatic approach to diagnostic imaging. Eur J Orthop Surg Traumatol 2014; 24 : 1237-41.

10. Geirsson AJ, Statkevicius S, Vikingsson A. Septic arthritis in Iceland 1990-2002: increasing incidence due to iatrogenic infections. Ann Rheum Dis 2008; 67: 638-43.

11. Della Valle C, Parvizi J, Bauer TW, Dicesare PE, Evans RP, Segreti J, et al. Diagnosis of periprosthetic joint infections of the hip and knee. J Am Acad Orthop Surg 2010; 18: 76070 .
12. Osmon DR, Berbari EF, Berendt AR, Lew D, Zimmerli W, Steckelberg JM, et al. Diagnosis and management of prosthetic joint infection: clinical practice guidelines by the Infectious Diseases Society of America. Clin Infect Dis 2013; 56: e1-e25.

13. Mathews CJ, Weston VC, Jones A, Field M, Coakley G. Bacterial septic arthritis in adults. Lancet 2010; 375: 846-55.

14. Parvizi J, Zmistowski B, Berbari EF, Bauer TW, Springer BD, Della Valle CJ, et al. New definition for periprosthetic joint infection: from the Workgroup of the Musculoskeletal Infection Society. Clin Orthop Relat Res 2011; 469: 2992-4

15. Jamsen E, Stogiannidis I, Malmivaara A, Pajamaki J, Puolakka T, Konttinen YT. Outcome of prosthesis exchange for infected knee arthroplasty: the effect of treatment approach. Acta Orthop 2009; 80: 67-77.

\section{ENGLISH SUMMARY}

\section{Infection of a total knee replacement following repeated joint aspiration - a case report}

Eypór Örn Jónsson ${ }^{1}$, Hera Jóhannesdóttir², Anna Stefánsdóttir ${ }^{3}$

An 80-year old male presented with an infected knee replacement following repeated joint aspirations. They were carried out due to recurrent hemarthrosis resulting from an initially missed quadriceps tendon injury. The infection was eradicated first after arthrodesis. This case highlights that prosthetic joints are sensitive to infection, which once established can be difficult to eradicate. Careful consideration is necessary before aspirating prosthetic joints. Diagnosing quadriceps tendon injuries can be difficult and they must be included in the differential diagnosis of traumatic hemarthrosis. We review the initials steps in the diagnosis and management of periprosthetic joint infections.

${ }^{1}$ Department of Orthopedics, Sahlgrenska University Hospital, Gothenburg, Sweden ${ }^{2}$ Department of Orthopedics, Landspitali University Hospital, Reykjavik, Iceland, ${ }^{3}$ Lund University, Skane University Hospital, Department of Clinical Sciences Lund, Orthopaedics, Lund, Sweden

Key words: periprosthetic joint infection, total knee replacement, quadriceps tendon rupture, hemarthrosis, joint aspiration.

Correspondence: Eypór Örn Jónsson, eythororn@gmail.com 